\title{
A Review of the Impact of Reforms on Financial Viability and Sustainability of Tanzania's Power Sector
}

\author{
James Andilile ${ }^{1}$, \& Saganga Mussa Kapaya ${ }^{2}$ \\ ${ }^{1}$ Business Management, Open University of Tanzania, P.O . box 23409, Dar es Salaam, Tanzania \\ ${ }^{2}$ Dr., Business Management, Open University of Tanzania, P.O . box 23409, Dar es Salaam, Tanzania \\ Correspondence: James Andilile, Business Management, Open University of Tanzania, P.O . box 23409, Dar es Salaam, \\ Tanzania.
}

Received: October 9, 2021

doi:10.11114/aef.v8i6.5398

\author{
Accepted: November 2, $2021 \quad$ Available online: November 5, 2021
}

URL: https://doi.org/10.11114/aef.v8i6.5398

The research is self-financed by the corresponding author as part of his PhD project.

\begin{abstract}
In Tanzania, reforms were mooted in the 1990s to solve two intertwined problems; the financing of investment and reducing the fiscal drain on the government to the sector. This study deploys the ARDL Model and paired-sample t-statistic tests, with profitability and liquidity data from 1989 to 2020 to examine the impact of the reforms on sectoral financial condition in Tanzania. The results suggest that both profitability and liquidity did not significantly improve after reforms. Apart from commercialization policy, other variables were not statistically significant with privatization and liberalization law exerting a negative pressure on liquidity. The findings, therefore, appear to contradict the theoretical view that the reforms improve the financial condition of both the sector and the governments. The outcome can be explained by unfinished reforms manifested by continued politicization of the sector hence underpricing and underinvestment. To ensure sectoral financial viability and sustainability we recommend that the reform policies such as commercialization, corporatization, and independent regulation should be prioritized. These findings will add value to policymakers in Tanzania and beyond which are reforming their power sectors by recognizing that efficient pricing and investment are key for a viable and sustainable financial condition of the sector.
\end{abstract}

Keywords: reforms, liquidity, and profitability

\section{Background}

In Tanzania, electricity was introduced in 1908 by the Germans. In 1922, Great Britain formed the Government Electricity Department to manage the public electric facilities left by the Germans. In 1931, these facilities were privatized to Tanganyika Electric Supply Company Ltd (TANESCO) and Dar es Salaam and the District Electric Supply Company Ltd (DARESCO). To marshal the needed industrialization agenda and accelerate access to electricity, in 1964, the two companies were merged. In 1975, the government acquired all shares in the merged company to form a state monopoly company, Tanzania Electric Supply Company Ltd (TANESCO). Thus, the government became the sole investor in the sector. This policy was promulgated on the basis that investment in the sector is capital intensive and that if left to the private sector would only maximize profits rather than societal welfare.

Until the early 1980s, the power sector in Tanzania performed well. Later its performance started to deteriorate due to underinvestment caused by the government fiscal crisis. The crisis was triggered by the 1970s global economic crisis, the Tanzania-Uganda war, the East African Community dissolution, and droughts that led to power supply shortages. It was further intensified by the decline in donor's support and shift in lending policies and priorities, the 1986 currency devaluation leading to below-cost tariffs, and power supply shortages due to droughts (Ghanadan and Eberhard, 2007). By the 1990s, the sector thus became dysfunctional. After a long period of state monopoly, in the 1990s, Tanzania began reforms which are anchored on the market-oriented institutional change theories by encouraging privatization and competition in the sector. It was hoped that the change in ownership from public to private sector and introduction of competition would improve performance due to the quest for profits and survival. 
Like most countries, Tanzania adopted the standard reform model which entails the introduction of liberalization law, independent regulation, independent power producers, unbundling, corporatization, commercialization, energy fund, privatization, and competition (see Lee and Usman, 2018; Yang and Urpelainen, 2019). It was theoretically believed that reforms would jump-start the performance and maximize societal welfare (Lee and Usman, 2018). In 1992, Tanzania thus issued the first national energy policy to liberalize the sector. Except for unbundling, Tanzania has attempted to implement almost all elements of the standard reform model (see Appendix 1). These interventions inter alia were directed to improve the financial condition of both the sector and government by promoting efficient pricing of electric service and attracting private capital.

Despite the promises, it appears that the sector has continued to exhibit similar characteristics as before reforms. Initial studies (Eberhard and Godinho, 2017; Pueyo and Bawakyillenuo, 2017) suggest that the reforms did not improve the financial condition as the sector continues to suffer from inefficient pricing leading to a de facto permanent financial crisis. This challenge existed before reforms and was among the main reasons of the reforms. Theoretically, the reforms were hoped to fix this conundrum of the sector. This paper attempts to contribute to the ongoing debate on whether the reforms improve the financial condition of both the sector by reflecting on Tanzania. It is hypothesized that in Tanzania the reforms have not significantly and positively improved the profitability and liquidity of the sector.

\section{Literature Review}

From the theoretical front, Sen, Nepal, and Jamasb (2016) cite that there is no universal theory that governs the reforms but much of its underlying logic has the foundation in microeconomic and industrial organization theories. These theories such as the laissez-faire theory which its foundation is accredited to Adam Smith (1776) postulates that under perfect competition and private ownership the sectoral performance improves and the welfare of society maximized whereas monopoly can lead to a deadweight loss. According to theory, the self-interest entrenched in private ownership becomes the driving force for an economic agent to operate efficiently while competition serves as a regulator of economic activities. In the power sector, Jamasb, Sen, and Nepal (2016) indicate that competition eliminates managerial slack, undermines the need for subsidies, and incentivizes management to operate efficiently.

The 1990s' reforms were founded on a belief that a change from state monopoly to a competitive power market would foster efficient pricing of electric service thereby improving the financial condition of both the sector and governments. The efficient pricing was to stem from subjecting the tariffs determination to market forces or independent regulation (Lee and Usman, 2018). For governments the improvement was to come from reduced government subsidies and spending to the sector, increased revenues from privatized corporations (taxes and dividends), and proceeds from the sale of state-owned enterprises' shares or assets (Besant-Jones, 2006; World Bank, 2016). The sectoral improvement was to emanate from depoliticization of tariff setting matters, enhanced operational efficiency and labour productivity, improved management style and accountability, use of new technologies, effective organizational structure, and growth in IPPs (Eberhard, Rosnes and Shkaran, 2011).

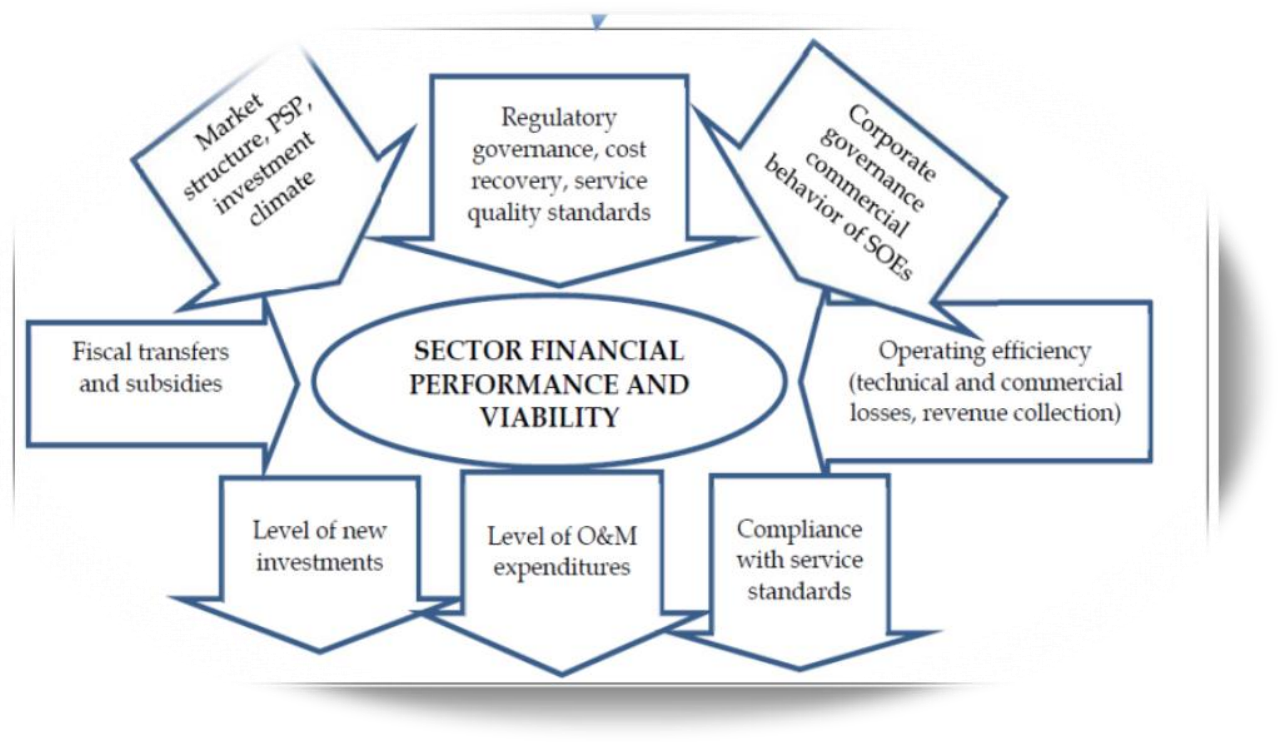

Source: World Bank, 2016

Figure 1. Financial Viability Indicators 
According to Wooders, Bridle, and Nguyen (2014), a firm is said to be financially viable and sustainable only when can sustainably provide adequate power, invests, generate adequate revenues to cover costs, and complies with social and environmental norms. Figure 1 illustrates the key elements of a financially viable sector. The financial soundness of the power sector determines the scale and speed of investment, electrification rates, service quality, and private sector participation. The reforms therefore solve the intertwined problems of financing investment and fiscal drain on governments to the sector.

In countries where at the time of initial reforms prices were below cost, the reforms, helped bring the tariffs to cost-reflective levels (Kessides, 2012; Sen et al. 2016). In developing countries depoliticizing tariff matters is however limited as subsidizing the service is politically more attractive than raising the tariffs (Rud, 2009). Empirically, so far, several studies have been done to investigate the impact of reforms on sectoral financial condition but with varying results. In Namibia, Colombia, and 20 developing countries, for instance, Kapika and Eberhard (2010), Pombo and Taborda (2006), and Eberhard et al. (2011) respectively, saw that after the reform's profitability (cost recovery) had improved significantly.

Likewise, using Fixed Effect (FE) Model for data from 114 largest companies in Russia, Abramov, Radygin, Entov, and Chernova (2017) found that change in ownership structure and labour productivity characteristics in the sector had improved profitability after the reforms. In Chile and Brazil, Fisher, Gutierrez, and Serra (2004) and Mota (2003) respectively uncovered a substantial increase in profitability after privatization. In Norway, Bye and Hope (2005) determined that the power market deregulation had increased the return on capital. In contrast, Quiggin (2014) exposes that in Australia sectoral profitability and the government's fiscal space did not improve after privatization. Victor (2005) thus confesses that privatization does not make the sector profitable but generates early income to cash broke governments. On the other hand, Ullah (2015) observed that developing countries that only opted for IPPs without divestiture faced difficulties in improving their overall financial condition. Using data from 49 developing countries, the World Bank (2016) saw that after the reforms the cost recovery did not improve. Applying the FE Model for data (1985-2000) from 51 developing countries, Zhang, Parker, and Kirkpatric (2008) found that the reforms did not improve profitability as the influence of independent regulation on the cost-of-service remained insignificant.

According to Besant-Jones (2006), the commercialization of power utilities in developing economies is limited by political interference in the sector, lack of autonomous regulatory bodies, large cross-subsidies, customers' resistance to tariff increase due to poor service, financial mismanagement, and inadequate government subsidies. The World Bank (2016) reports that underinvestment and underpricing have led power utilities in Sub-Saharan Africa - SSA, to remain in a de facto permanent financial crisis with significant reversals in profits. Jamasb, Mota, Newberry, and Pollitt (2005) thus confess that the reforms have faced considerable difficulties in most countries as champions underestimated the political challenge of moving tariffs to cost-reflective levels. Rud (2009) admits that enhancing cost recovery requires integrated approaches that include tariff adjustments, improved revenue collection, reduction in system losses, effective expenditures control, and sufficient and predictable transfers from governments. In Tanzania, Pueyo and Bawakyillenuo (2017) admit that despite the reforms TANESCO has endured a precarious financial situation leading to chronic underinvestment in the sector. Equally, Godinho and Eberhard (2018) indicate that tariffs in Tanzania have remained below cost affecting both sectoral technical and financial performance.

In terms of liquidity, Besant-Jones (2006) suggests that the reforms improve the financial position of both the sector and governments. But the outcome from one reforming countries varies. In Latin America, for example, after the reforms, the fiscal performance of governments had improved due to increased taxes and dividends and a reduction in governments' subsidies to the sector (World Bank, 2003). In contrast, Byrne, Glover, Lee, Wang, and Yu (2004) uncovered that in South Korea, the reforms failed to solve the problem of indebtedness as the reforms were only a vehicle for private companies to acquire public assets and retiring the debts through higher tariffs. In Australia and developing countries, Quiggin (2014), and Rud (2009) respectively observed no significant improvement in the liquidity of both the sectors and governments after the reforms. Likewise, in Indian, Bhattacharyya (2007) found that the reforms did not improve the financial position of the sector nor reduce government subsidies.

Ullah (2015) claims that in most developing countries the reform objectives have not been met due to lack of appropriate institutions to support the reforms and political will to the reforms; public anxiety to reforms; political interference in management of utilities; weak regulatory framework; lack of separation of policy-making, regulation and ownership roles of the state; and wide-spread of subsidies in electricity tariffs. In most developing countries despite the reforms, the power sectors are still financially unsound and unprofitable with power utilities in SSA have been long technically insolvent, suffering from a structural operating deficit, and continued overreliance on government subsidies and loan guarantees to cover operating losses and investment (World Bank, 2016). In contrast, Kapika and Eberhard (2010) and Karekezi and Kimani (2002) saw that in Namibia and Uganda respectively the sectoral liquidity had 
improved after the reforms. In Tanzania, Mwandosya (2013) reveals that before the reforms sectoral regulation was inefficient and tariffs were politically determined.

TANESCO, therefore, failed to recover the operating costs, meet investment needs and financial obligations including servicing debts (Poudineh and Peng, 2016; Gratwick and Eberhard 2008). Thus, the sector had to rely on government subventions. The creation of EWURA in 2006, among other things, was meant to fix this problem. Both the EWURA Act of 2001, the Electricity Act of 2008, and the national energy policy of 2015 require tariffs to be cost-reflective. The question however remains, have reforms, the independent regulation specifically improved the financial viability and sustainability of Tanzania's power sector. The World Bank (2013) uncovers that despite the commercial focus of TANESCO being improved substantially after the reforms, still falls short of expectations as tariffs have not risen fast enough to achieve the operational cost recovery.

Equally, Godinho and Eberhard (2018) confess that despite various interventions and numerous bailouts, TANESCO has remained in a dire financial situation as tariffs in Tanzania have remained at below cost. The World Bank (2018) admits that with a quick ratio of 0.12 , Tanzania is among the more illiquid sectors in SSA. Victor (2005) reveals that where the reforms have not been advanced, the financial solvency of the sector did not improve. Likewise, Sen $e t$ al. (2016) indicate that where there are weak institutions, regulatory capture would lead to below-cost tariffs thus discouraging private investment, lead to poor service quality, and increasing the fiscal burden to governments. The World Bank (2016) points out that where the private sector is minimal, tariffs state-controlled and below cost, distribution companies sustain severe financial stress thus requiring frequent governments' bailouts to keep them afloat. Besant-Jones (2006) thus confess that in developing economies, the commercialization of electric services is limited by political interference and inefficient government subsidies. In the same vein, the World Bank (2017) presents that in most developing countries the legal, regulatory, and policy reform in the past 10 years have failed to put the sector on a firmer financial footing.

Despite the vast literature on the reforms, scholars (Govinda, Jamasb, and Nepal, 2015; Yang and Urpelainen, 2019) submit that so far there is no conclusive theoretical and empirical consensus about the economic gains of reforms which creates a knowledge gap both empirically and theoretically. Theoretically, the recent global experience suggests the presence of power supply crises even in highly liberalized markets and limited private sector ownership and competition (Jamasb, Sen and Nepal, 2016; Siami-Namini, 2017). In some predominantly public-owned sectors such as Norway, China, and Russia however significant improvement have been registered with some companies becoming competitive internationally (Chen and Shaofeng, 2005, Poudineh and Peng, 2016; Bye and Hope, 2005). This new evidence seems to suggest that the sectoral improvement is not merely a function of the ownership model, but rather complex factors including sectoral governance. This revelation, hence, widens the theoretical gap which necessitates further research.

Empirically, an evidence gap exists as the outcome of the reforms are mixed with both success and failure. This is partly explained by the differences in country-specific factors; the economic ideology, institutional factors, level of economic development, sector endowments, market structure, degree of market opening, and energy mix (Erdogdu, 2013; Sen et al. 2016). Nepal and Jamasb, (2012), thus suggest that since the reforms in most countries are still a work in progress, more studies should be done to unlock appropriate models for specific country. This study reflects on Tanzania. Methodologically, the improved financial condition was one of the main goals of the reforms. Regrettably, this goal has been under-researched as previous studies which were mostly qualitatively focused on service quality and investment as the two, according to Jamasb et al. (2016) were deemed the most important drivers of reforms. Our observation is that there is still a considerable uncertainty about the impact of the reforms on the financial condition of the sector and the government. Using profitability and liquidity as proxies for measuring the financial condition, this study intends to partly fill this methodological gap by applying the most recently developed Autoregressive Distributed Lag (ARDL) model to quantify the impact of reforms in Tanzania.

In Tanzania, it appears that irrespective of reforms, the sector still exhibits similar characteristics as before the reforms. However, knowledge gap exists as the subject matter has been understudied. Mwandosya (2013) admits that, despite the reforms, the outcome in Tanzania are not well known. Studies on the reforms have been limited and in most cases were based on cross-country analysis. Scholars (Besant-Jones, 2006; Lee and Usman, 2018) however suggest that the best way to assess the impact is at the country level. This study attempts to bridge this knowledge gap by examining the impact of reforms specifically in Tanzania. Overall, this study seeks to answer the question of whether the reforms have improved the financial viability and sustainability of the sector in Tanzania and whether the improvements (if any) can be directly linked to the reforms. It presents the theoretical and empirical evidence that unravel the existing gap between the theory and practice about the reforms.

The results of this study will thus add value to Tanzania and beyond in several ways. First, policy lessons will aid policymakers in reforming countries with new and advanced knowledge about the reforms. Second, it will give scholars 
and researchers new insights and dynamics of the reforms both empirically and theoretically. Third, it will help the general public understand the progress and outcome of the reforms in Tanzania. The remaining sections of this paper are organized as follows. Section 2 presents the research methodology whilst section 3 discusses the findings of the study. Section 4 concludes the study by synthesizing policy recommendations and section 5 is an acknowledgement.

\section{Data and Methodology}

We used data for the period 1989-2020 separated into pre (1989-2005) and post the reforms period 2006-2020). The year 2006 was used as the baseline for after reforms as serious reforms in Tanzania only began when Energy and Water Utilities Regulatory Authority (EWURA) became operational in 2006. The year 2020 was the last year for which data were available at the time of research. To ensure data quality limited data sources with legal custodianship and mandates to publish them including TANESCO, Ministry of Energy, EWURA, National Audit Office, and National Bureau of Statistics were considered. The paired sample t-test and ARDL model were deployed in the analysis. The paired sample t-test was used to measure whether there is a significant difference in mean values as computed by STATA 13 between pre and post reforms periods. The ARDL model was applied to determine causality effects and cointegration between variables. The model is suitable for small samples, addresses the problems of autocorrelation and endogeneity among variables adequately, and is applied when the dependent variables are I(1) and the rest of the variables are either I(1) or (0) or both. This model is analogous to those used by Zhang et al. (2008), Polemis (2016) and Jamasb et al. (2016).

We performed the stationarity test and determined the appropriate lags using the Augmented Dickey-Fuller (ADF) Unit Root Tests and Akaike Information Criterion (AIC) respectively. The cointegration between variables was analyzed using the ARDL Bounds testing approach. The coefficients of variables, serial correlation, the function of form, normality and heteroscedasticity, and parameters stability tests were both calculated using MICROFIT Software 5.5; one of the most powerful menu-driven time-series econometric packages currently available. It has a range of diagnostic and non-nested tests that are not readily available in other packages. Independent variables used conforms to the standard reform model. Unbundling was excluded as is yet to be implemented in Tanzania. The IPP was blended into privatization as they occurred concurrently hence difficult to separate their effects. The independent variables were ranked between 0 and 4 depending on the level of progress from the ideal competitive market in line with the recommendations by Erdogdu (2013). The measurement variables were defined as follows:

Profitability Index $\left(P I_{t}\right)$ measures the ability of a firm's revenues to cover the costs. It is determined as a difference between total revenues and total costs, the net profits/losses (Wooders, Bridle and Nguyen, 2014). Simply put profit after tax is used as a proxy of profitability and costs recovery measures. For a profitable business operation, the cost recovery (Revenue/cost) rate lies between $110 \%$ and $115 \%$ (Wooders et al. 2014). The increase in profit after tax signifies improvement.

Liquidity Index $\left(L I_{t}\right)$ measures the ability of a firm to meet its financial obligations when they fall due for payment (Wooders et al. 2014). It is calculated by dividing total current assets by total current liabilities. Any ratio below one implies that the firm has difficulties in meeting its financial obligations (ibid). The increase in the current ratio to 1 signifies improvement.

The measurement variables were selected for several reasons. First, they were the main drivers of the reforms in most countries. Second, previous studies (Zhang et al. 2008; Kapika and Eberhard, 2010; Wooders et al. 2014) used similar variables though in a piecemeal fashion. Third, they are consistent with the World Bank's (2009) indicators for measuring performance in SSA. The next section presents the empirical findings and discussions of the study.

\section{Results and Discussion}

The discussion is based on the results from the paired sample t-test and ARDL Model. Profitability data contained both positive and negative integers, hence model automatically rejected them. Its discussion was thus mainly based on the analytical review.

Table 1 establishes that the variables are integrated of order I(1) and become stationary at their first differences making the use of the ARDL Model plausible. 
Table 1. ADF Unit Root Tests Results

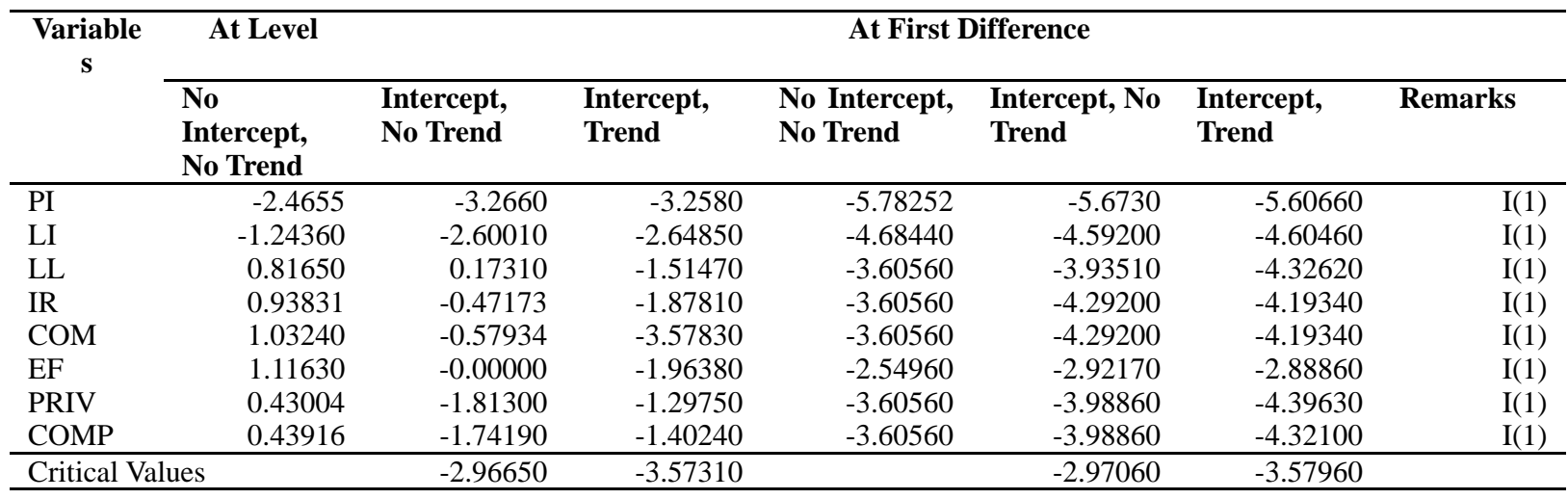

Source: Author's computations based on MICROFIT 5.5

Table 2. Bound Tests for Cointegration

\begin{tabular}{lllcll}
\hline Dependent Variab. & F-Statistic & [Prob.] & 99\% & Conclusion \\
\cline { 2 - 5 } & & & $\mathbf{I}(\mathbf{0})$ & \\
& & & I(1) & \\
\hline DLI & 4.82710 & {$[0.074]$} & 3.267 & 4.54 & Cointegration \\
\hline
\end{tabular}

Source: Author's Computations using MICROFIT 5.5

Estimated using the F-Statistics, the integration results in Table 2 are fairly higher than the tabulated Critical Upper-Bound values of 4.54 at a $99 \%$ level of significance. Thus, the null hypothesis of no co-integration among variables is rejected.

Table 3. Paired Samples t-test Results

\begin{tabular}{|c|c|c|c|c|c|c|c|c|c|}
\hline \multirow{3}{*}{ Variables } & \multicolumn{5}{|c|}{ Paired Differences } & \multirow[t]{3}{*}{$\mathbf{T}$} & \multirow[t]{3}{*}{ Df } & \multirow{3}{*}{$\begin{array}{l}\text { Sign } \\
\text { (2-tailed } \\
\text { ) }\end{array}$} & \multirow{3}{*}{$\begin{array}{c}\text { Remarks } \\
\text { on Ho }\end{array}$} \\
\hline & \multirow[t]{2}{*}{ Mean } & \multirow{2}{*}{$\begin{array}{l}\text { Std } \\
\text { Deviation }\end{array}$} & \multirow{2}{*}{$\begin{array}{l}\text { Std. } \\
\text { Error } \\
\text { Mean }\end{array}$} & \multicolumn{2}{|c|}{$\begin{array}{l}\text { 95\% CI of the } \\
\text { Difference }\end{array}$} & & & & \\
\hline & & & & Lower & Upper & & & & \\
\hline $\begin{array}{l}\text { PRE_PI - } \\
\text { POST_PI }\end{array}$ & $-22,200.00$ & $26,616.67$ & $6,654.17$ & $-36,350.15$ & $-7,984.10$ & -3.33 & 15.00 & 0.005 & Reject \\
\hline $\begin{array}{l}\text { PRE_LI - } \\
\text { POST_LI }\end{array}$ & -0.08 & 0.68 & 0.19 & -0.49 & 0.34 & -0.40 & 12.00 & 0.6970 & $\begin{array}{l}\text { Do not } \\
\text { reject }\end{array}$ \\
\hline
\end{tabular}

Note: $\mathrm{PI}=$ profitability Index, LI= Liquidity Index

Source: Author's computations based on STATA 13.

Table 3 indicate that there is a significant difference in mean values between before and after the reforms for profitability but not for liquidity as lossess have increased enomously. The null hypothesis that the reforms had no significant impact on profitability is thus rejected since $p<0.05$. In the case of liquidity since $p>0.05$, we are however unable to reject the null hypothesis that the reforms have no statistically significant positive impact.

\subsection{Reforms and Profitability}

Contrary to our expectations, we found that instead of improving profitability worsened after the reforms. Our findings appear to confirm previous studies (Quiggin, 2014; World Bank, 2016) that the reforms do not necessarily improve profitability. They however challenge earlier research (Kapika and Eberhard, 2010; Abramov et al. 2017) that the reforms improve profitability. The outcome, therefore, seems to support the laissez-faire theory that efficient pricing is plausible only when the sector is subjected to independent regulation and market forces, both of which seem to be missing in Tanzania. The outcome can broadly be connected to underinvestment and underpricing in the sector. 
During droughts, underinvestment and inefficient energy mix have pushed the country into repetitive procurement of costly Emergency Power Plants - EPPs. For instance, in 2012, more than 50\% of the energy generated was coming from hydropower systems. The hydropower systems are normally susceptible to weather variation. Hence, sectoral profits were largely affected by the variations in the hydrological conditions. During the droughts in 2012 TANESCO for example was compelled to contract costly EPPs to bridge the capacity deficit (see Figure 2). In 2013, while EPPs supplied about $11 \%$ of the energy generated, their costs accounted for around $43 \%$ of generation costs, putting TANESCO on the verge of bankruptcy (Eberhard et al. 2018).

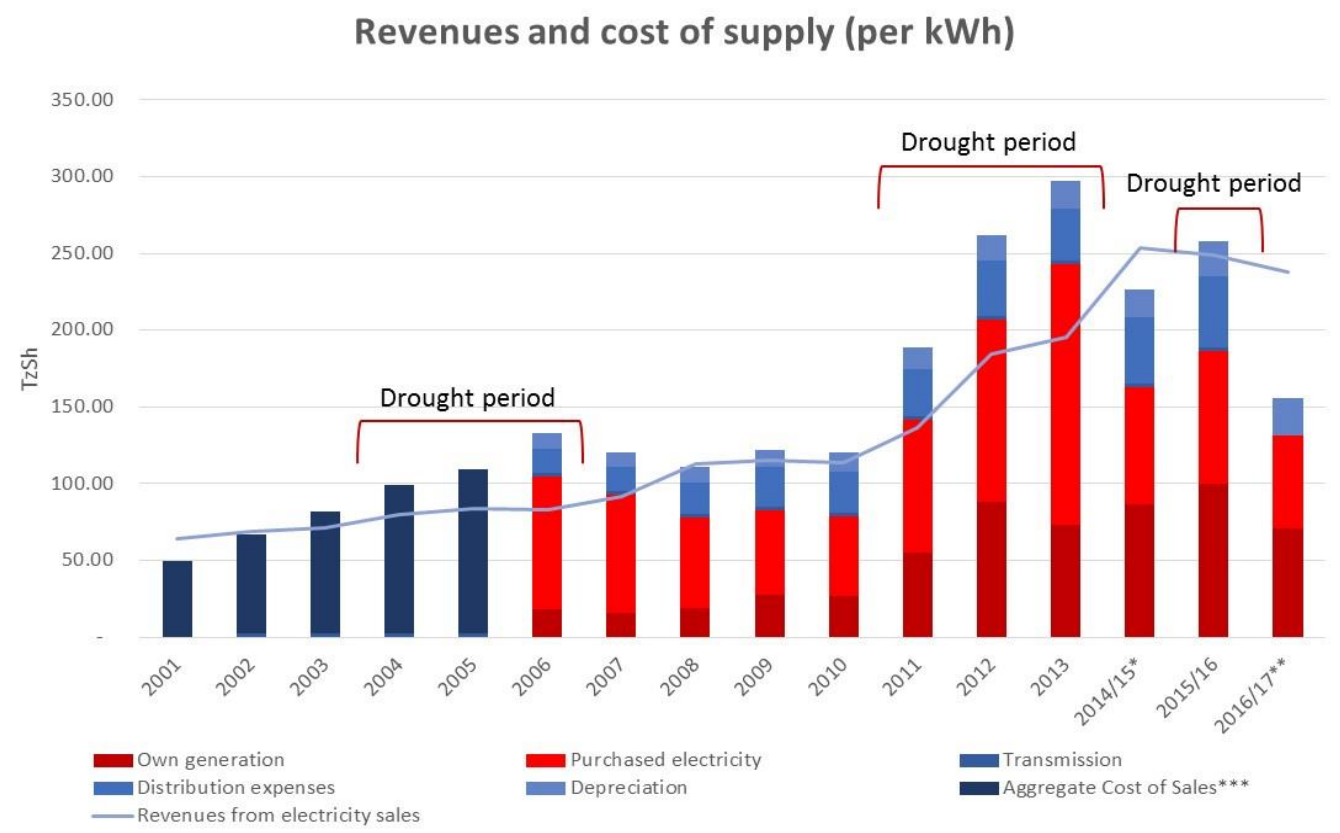

Figure 2. Revenue Adequacy Trends

Source: World Bank (2018)

Godinho and Eberhard (2018) claim that in Tanzania investment is suboptimal because of a lack of coherent and up-to-date power sector planning as the planning is characterized by short-term politics, rather than technically sound, long-term processes, and lines between planning, policy, and procurement are frequently transgressed.

Underpricing is manifested by the inability of TANESCO's revenue to cover the costs. For instance, during the droughts in 2012, while average tariffs were US\$c16/kWh, the average costs of EPPs were around US\$c 40/kWh1. Thus, the power crisis progressed into a financial crisis to both the government and TANESCO as tariffs failed to sufficiently cover the cost. According, NAO (2017), the loss making position of TANESCO can be linked to the fact that it buys electricity from EPP/IPPs at TZS 544.65/kWh and sell for TZS 279.35/kWh.

${ }^{1}$ The weighted average composed of Symbion-Ubungo 0.19/kWh; Aggreko Ubungo-0.39/kWh; Aggreko Tegeta 0.40/kWh; Symbion Dodoma 0.78kWh; Symbion Arusha 0.80/kWh. 


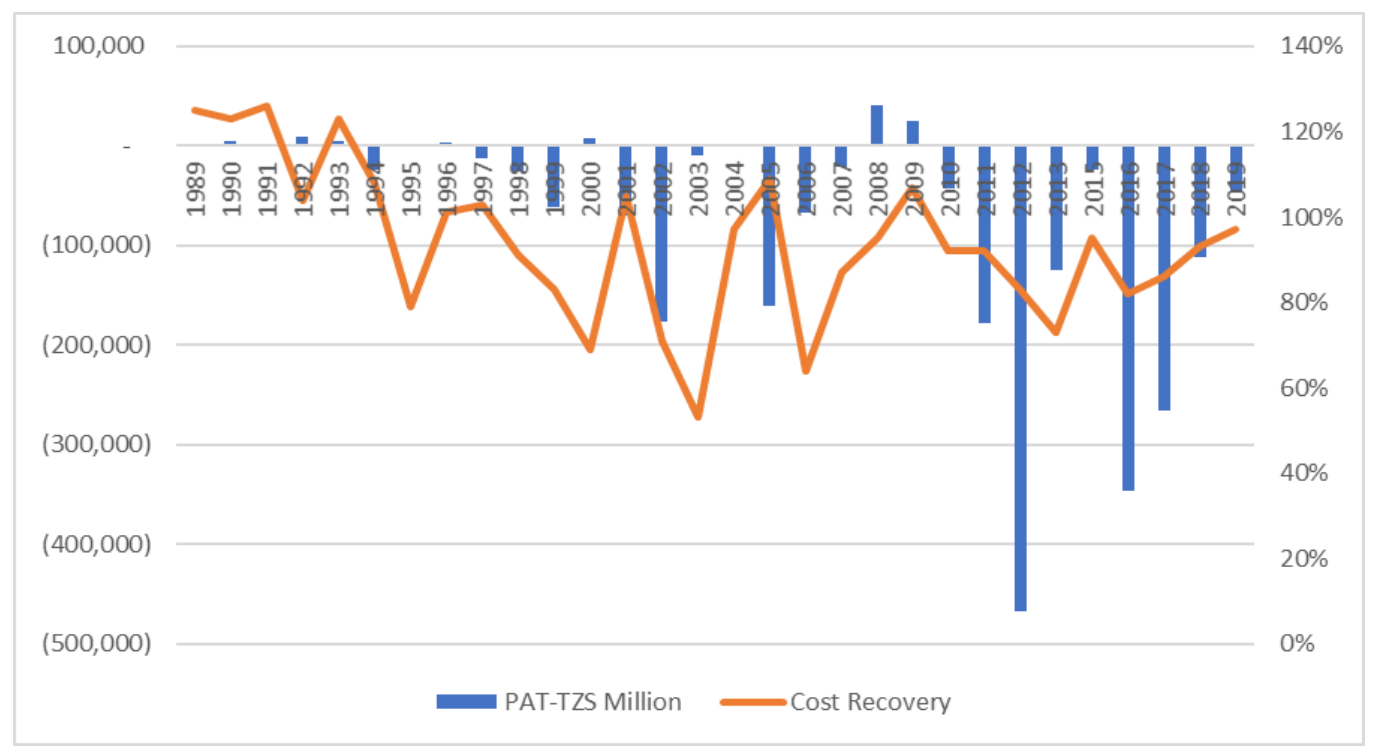

Figure 3. Profitability and Cost Recovery Trends

Source: Author, 2021 based on data from TANESCO 1989-2020

Figure 3 reveals that most of the time cost recoveries have been below 100\% suggesting that TANESCO is not breaking even in its operation. Eberhard et al. (2011) uncover that the depoliticization of tariff matters improves the financial performance of the sector. Thus, underpricing in Tanzania can be connected to government interferences in tariff setting matters. For instance, in 2016 the government compelled EWURA to reduce the tariffs by $2 \%$ after it has commissioned the National Natural Gas Infrastructure through TPDC. Equally, in 2017, the 8.53\% tariff rise approved by EWURA was turned down by the government for no apparent reason. The result is consistent with former findings (Zhang et al. 2008) that independent regulators can lead to better financial performance, but in most developing countries, their effect on cost-reflective pricing is insignificant. In Tanzania, it appears that the government has failed to grant EWURA adequate mandates to adjudicates tariff matters. Our reflection corroborates well with the findings by Pueyo and Bawakyillenuo (2017) that to succeed, reforms must be politically desirable and technically feasible. From the results we can, therefore, infer that the reforms in Tanzania have not improved the profitability of the sector but rather worsened it. The most relevant policy inference from the results is that regardless of the form of ownership, efficient pricing of electric service should be prioritized to ensure profitability and overall financial viability and sustainability of the sector

\subsection{Reforms and Liquidity}

In our analysis, we have as well determined that sectoral liquidity did not improve after the reforms.

Table 4. ARDL Output for Liquidity Index

30 Observations used for Estimation from 1989 to 2020

\begin{tabular}{|c|c|c|c|c|}
\hline Regressor & Coefficient & Standard Error & T-Ratio & [Prob.] \\
\hline $\mathrm{LI}(-1)$ & 0.563230 & 0.279950 & 2.011900 & {$[0.072]^{*}$} \\
\hline $\mathrm{LI}(-2)$ & -0.568830 & 0.361220 & -1.574700 & {$[0.146]$} \\
\hline LL & -0.048172 & 0.216000 & -0.223020 & {$[0.828]$} \\
\hline $\operatorname{LL}(-1)$ & 0.083635 & 0.178550 & 0.468420 & {$[0.650]$} \\
\hline $\operatorname{LL}(-2)$ & -0.294860 & 0.175850 & -1.676800 & {$[0.125]$} \\
\hline IR & 0.606990 & 0.444630 & 1.365200 & {$[0.202]$} \\
\hline $\operatorname{IR}(-1)$ & 0.094795 & 0.347520 & 0.272780 & {$[0.791]$} \\
\hline $\operatorname{IR}(-2)$ & -0.349590 & 0.229180 & -1.525400 & {$[0.158]$} \\
\hline COM & 0.625260 & 0.304440 & 2.053800 & {$[0.067]^{*}$} \\
\hline $\operatorname{COM}(-1)$ & 0.328580 & 0.305520 & 1.075500 & {$[0.307]$} \\
\hline $\operatorname{COM}(-2)$ & -0.541520 & 0.292780 & -1.849600 & {$[0.094]^{*}$} \\
\hline $\mathrm{EF}$ & -0.929940 & 0.440420 & -2.111500 & {$[0.061]^{*}$} \\
\hline PRIV & -1.059000 & 0.650720 & -1.627500 & {$[0.135]$} \\
\hline $\operatorname{PRIV}(-1)$ & -1.415200 & 0.601920 & -2.351100 & {$[0.041]^{* *}$} \\
\hline $\operatorname{PRIV}(-2)$ & -2.152900 & 0.527450 & -4.081800 & {$[0.002]^{* * *}$} \\
\hline
\end{tabular}




\begin{tabular}{lcccc} 
COMP & 0.997740 & 0.654890 & 1.523500 & {$[0.159]$} \\
COMP(-1) & 2.492800 & 0.601050 & 4.147400 & {$[0.002]^{* * *}$} \\
COMP(-2) & 0.714850 & 0.321680 & 2.222300 & {$[0.050]^{* *}$} \\
TREND & 0.077088 & 0.032446 & 2.375900 & {$[0.039]^{* *}$} \\
\hline R-Squared & 0.88745 & R-Bar-Squared & 0.68485 & \\
S.E of Regression & 0.24826 & F-stat. F(18,10) & $4.3803[0.011]$ & 0.44223 \\
Mean of Dep. Var. & 0.68103 & S.D of Dep.Var. & 14.6942 & -17.2951 \\
RSS & 0.61633 & Equat LL & & $90 \%$ UB \\
AIC & -4.3058 & SBC & $90 \%$ LB & 3.7849 \\
DW-statistic & 1.7376 & & 2.487 & $90 \%$ UB \\
\hline F-statistic & $95 \%$ LB & $95 \%$ UB & $90 \%$ LB & 26.4944 \\
4.1480 & 3.0258 & 4.5091 & 17.4087 & \\
W-statistic & $95 \%$ LB & $95 \%$ UB & & \\
29.0358 & 21.1804 & 31.5636 & &
\end{tabular}

\section{Diagnostic Tests}

Serial Correlation, CHSQ(1)=0.78459[0.376]: Lagrange multiplier test of residual serial correlation

Functional Form, CHSQ(1)=1.4535[0.228]: Ramsey's RESET test using the square of the fitted

values

Normality, $\operatorname{CHSQ}(2)=0.23842[0.888]$ : Based on a test of skewness and kurtosis of residuals

Heteroscedasticity, CHSQ(1)=0.17716[0.674]: Based on the regression of squared residuals on squared fitted values

Note: $* * *, * *$ and $*$ denote $1 \%, 5 \%$ and $10 \%$ level of significance

Source: Author's Computations using MICROFIT 5.5

Table 5 demonstrates that only commercialization policy is statistically significant and influenced the liquidity position positively. The coefficients of independent regulation and competition are positive albeit not statistically significant. The privatization and liberalization law on the other hand exerted a negative pressure on liquidity though not statistically significant. Figure 5 indicates that most of the time the liquidity ratio for the sector has been below 1 suggesting that TANESCO is financially distressed. The results verify the previous findings (Poudineh and Peng, 2016; Rud, 2009; World Bank, 2016) that the reforms do not necessarily improve the sectoral financial liquidity. They however dissent from earlier results (Besant-Jones, 2006; Kapika and Eberhard, 2010; Karekezi and Kimani 2002) that the reforms improve the liquidity of the sector. The outcome does not support the laissez-faire theory that the market-oriented reforms improve the financial condition of both the sector and governments as they contribute towards achieving efficient pricing of electric service. Tanzania's experience seems to confirm earlier findings (Ullah, 2015) that developing countries that only opted for IPPs without divestiture faced difficulties in improving their overall financial condition.

Cooksey (2017) claims that since 2002 when IPTL came on stream TANESCO has remained in a chronic insolvency situation as it has been paying more to IPPs and EPPs than it can charge the customers. As before the reforms, with a liquidity ratio of less than one most of the time, it implies that the sector has continued to suffer from a liquidity squeeze (Figure 4). The situation is further confirmed by the World Bank (2018) that with a quick ratio of 0.12, Tanzania is among the more illiquid sectors in SSA. The politicization of the sector manifested by perpetual government interference in pricing and investment decisions is perhaps the main cause for the overall sectoral underperformance. Our results are hardly distinct from that of Pueyo and Bawakyillenuo (2017)) that regardless of the reforms, the financial situation of the sector in Tanzania has not improved. The World Bank (2018) further shows that despite collection efficiency of $92 \%$, system losses of $18 \%$, and cost recovery of $93 \%$, by 2018, TANESCO has failed to translate this relatively better operational performance into an improved liquidity position. 


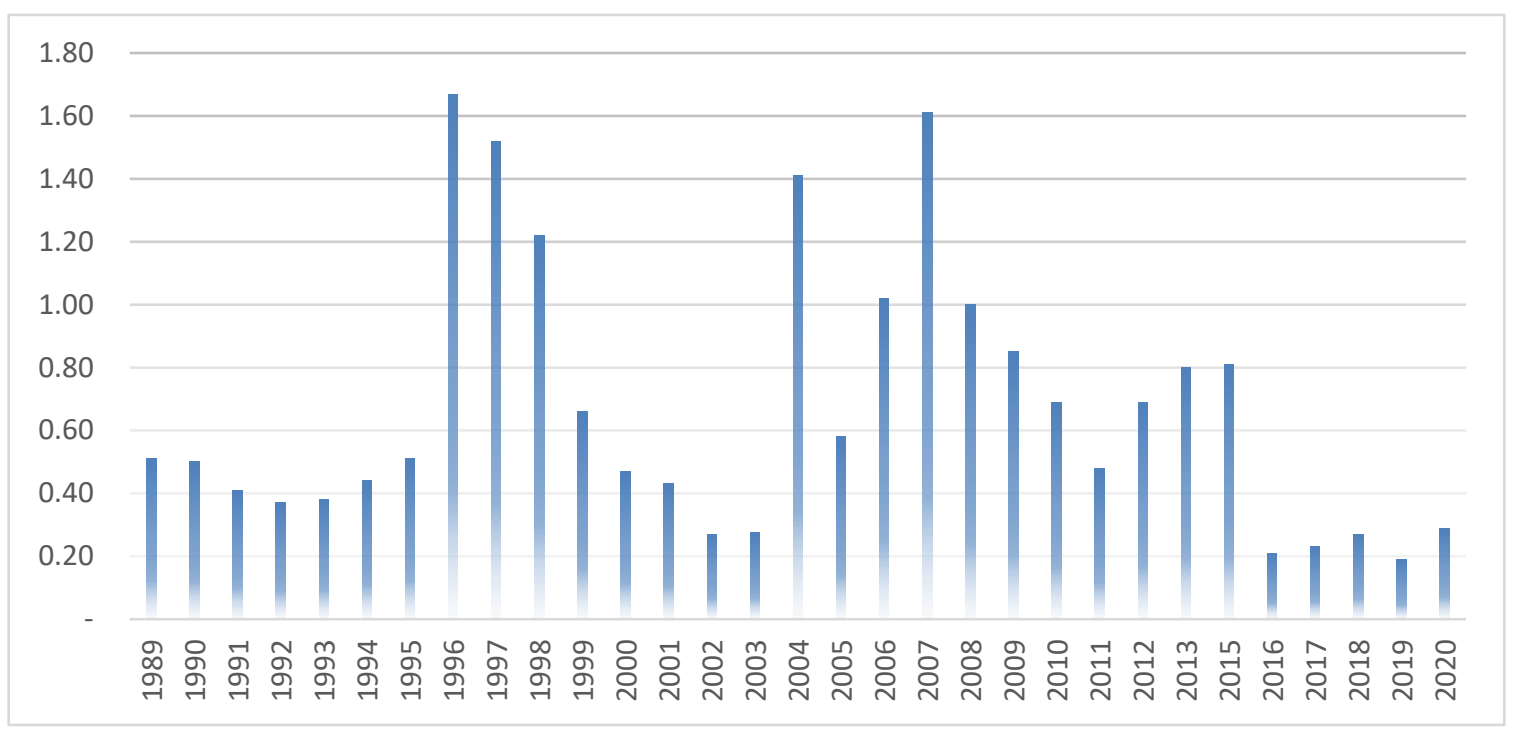

Figure 4. Liquidity Trends

Source: Author, 2021 based on data from TANESCO 1989-2020

The underpricing and underinvestment, have repeatedly compelled the government to bailout TANESCO's investment and operation costs. According to the World Bank (2018) between 2012 and 2016, the government made transfers to TANESCO of about US $\$ 249$ million as operating subsidies. The World Bank (2016)however links the continued weak sectoral liquidity position of TANESCO to insufficient government transfers, too low net revenues, and growing indebtedness. Hypothetically, IPPs were meant to reduce the fiscal burden of the government. Cooksey (2017) however reveals that IPPs can lead to economic growth and improved livelihoods only when are procured competitively, negotiated transparently, and backed up by effective planning and regulatory systems both of which seem to be missing in Tanzania. While IPPs were contracted competitively, political interference in the procurement process, lack of proper planning, and inefficient regulation rendered scandalous deals (IPTL and Richmond) to be sanctioned. For example, while the average tariff was US\$c $8.73 / \mathrm{kWh}$ the ministry of energy negotiated the PPA with IPTL on behalf of TANESCO for US $\$ c 21.5 / \mathrm{kWh}$. Tanzania experience stands well with former findings (Pollitt, 1995) that the government's interference in investment decisions increases the costs.

In Tanzania, the weak financial condition is further demonstrated by the stockpiling of power and fuel suppliers' arrears which have blocked the entire sector from operating efficiently. The supplier arrears have their origin in the 1990s when Tanzania began contracting EPPs without raising tariffs to cost of service. NAO (2017) admits that tariffs approved by the regulator do not reflect the actual cost of service inhibiting TANESCO's ability to effectively carry out its mandates including paying outstanding debts. The NAO (2020) uncovered that by June 2019, the suppliers' arrears stood at US\$414 million (TZS 938.5 billion). The continued TANESCO's financial distress has thus hampered the overall development and sustainability of the sector as the timely recovery of investment is not guaranteed to private investors. Tanzania's experience seems to mirrors Pakistan where Ullah (2015) determined that the power utilities failed to recover the full cost of electricity supply from end-use customers leading to a debt surge.

The worsening of liquidity position can also be related to the deficiency in the subsidy policy. Too low-end users' tariffs imply that TANESCO is subsidizing consumers, which in turn prevents further investment in the sector and affects the sustenance of the service provisions. Unlike other infrastructure sectors such as the telecommunication sector, where consumers pay for the cost of service regardless of their income status, in the power sector, poor households using up to $50 \mathrm{~kW}^{2}$ per month are supplied at below-cost tariffs. While the scheme is socially necessary to protect the welfare of the poor, TANESCO is however not compensated for the lost revenue which adds to its financial hardship. In this study, we observed that after the reforms, the liquidity position of the sector did not improve as predicted. From these results we can, therefore, infer that the reforms have not significantly contributed to improving the financial position of the power sector in Tanzania.

\footnotetext{
${ }^{2}$ Previously the units per months were 1000kWh in 1992; 500kWh in 1995 and 100kWh in 2002
} 
The key policy implications of the findings are twofold; first insufficient capacity due to underinvestment affects the financial position of the sector and the progress of the reforms. Second, efficient planning explained by the timely investment of the Least Cost Plan based on the diversified energy mix can help improve the financial condition of the sector and therefore should be encouraged. Overall, our empirical findings suggest that profitability and liquidity did not improve after the reforms largely due to the politicization of the sector leading to underpricing, the unfinished reforms as TANESCO continued operating in a de facto state monopoly fashion, and underinvestment which plunged the country into persistent power crises and lack of political will to reforms evidenced by the government reluctance to implement the reforms' best practices. The politicization of the sector is however perhaps the main binding constraint toward achieving overall sector performance and a threat to the progress and outcomes of the reforms in Tanzania.

This study has added to the literature on the reforms theoretically, empirically and methodologically. The theoretical contribution rests on the fact that improved sector governance is key for improved financial performance rather than a change in ownership structure. Methodologically, most of the previous studies in Tanzania were qualitative. To the best of our knowledge, this is probably among the first study to try to quantify the impact of reforms on the financial condition of the sector in Tanzania. Empirically, the impact of the reforms on performance has been extensively studied but different scholars came up with different conclusions. This study, therefore, has added value by unleashing new insights about the dynamics of the reforms by showing that limited private sector participation and competition and inefficient regulation affect sectoral performance. Practically, it is nearly two decades since Tanzania began the reforms. But the outcomes were not very well known. To the best of our knowledge, this is probably among the first to holistically quantify the impact of reforms on sectoral financial condition in Tanzania. The next section summarizes the main conclusion and policy implications.

\section{Conclusion and Recommendations}

This study was intended to examine the impact of the reforms on sectoral financial conditions in Tanzania. Our empirical findings suggest that after the reforms profitability and liquidity did not improve as predicted. The outcome may be associated with sectoral governance challenges manifested by the politicization of the sector, weak institutions and incomplete reforms. The results thus point to numerous policy directions. First, to ensure financial viability and sustainability of the sector, regardless of the ownership form efficient pricing of electric service should be prioritized.

Second, underinvestment and ineffective planning affect the sector's financial condition and the progress of the reforms. Thus, to ensure long-term secure supply and sustainable sectoral financial health, efficient planning epitomized by timely investment of the Least Cost Plan based on diversified energy mix should be encouraged.

Third, political pressure leading to underpricing and underinvestment seems to have inhibited the sector from attaining a viable and sustainable financial path. Thus, depoliticization of the sector by promoting commercialization, corporatization, competition, and independent regulation should be highlighted. Lastly, to achieve the first-best outcomes, we recommended that policymakers should promote better sector governance and predictable legal and regulatory frameworks.

Like most studies, this study is not without limitations. Some of the limitations are; small dataset due to the short history of the reforms and inadequate benchmarking of reform progress against neighbouring countries. As a result, as more data becomes available, more research along these spectrums may be conducted in the future.

\section{Acknowledgement}

I would like to thank my co-author, Dr. Saganga of the Open University of Tanzania for his fruitful comments and suggestions. Further, I express my deepest gratitude to Dr. Nicas Yabu for his support and insightful comments on a previous version of this paper. Any remaining errors belong entirely to the author. The usual disclaimer applies.

\section{References}

Abramov, A., Radygin. A., Entov, R., \& Chernova, M. (2017). State Ownership and Efficiency Characteristics. Russian Journal of Economics, 3, 129-157. https://doi.org/10.1016/j.ruje.2017.06.002

Besant-Jones, J. E. (2006). Reforming Power Markets in Developing Countries: What Have We Learned? Energy and Mining Sector Board Discussion Paper No. 19, September, The World Bank Group, USA.

Bhattacharya, S. (2007). Power Sector Reform in South Asia: Why Slow and Limited So Far? Energy Policy, 35(1), 317-332. https://doi.org/10.1016/j.enpol.2005.11.028

Bye, T., \& Hope, E. (2005). Deregulation of Electricity Markets: The Norwegian Experience. Economic and Political Weekly, 40(50), 5269-5278

Byrne. J., Glover, L., Lee,. H., Wang, Y., \& Yu, M. (2004). Electricity at a Crossroads: Problems in South Korea's Power Liberalization Strategy. Pacific Affairs, 77(3), 493-516 
Chen, W., \& Shaofeng, X. (2005). The reform of the Electric power sector in the PR of China. Shaofeng Xu, Wenying Chen 3E (Energy, Environment and Economy) Research Institute, Tsinghua University, Tsinghua, PR China Available online 21 July 2005.

Cooksey, B. (2017). IPTL, Richmond and "Escrow": The Price of Private Power Procurement in Tanzania. Africa Research Institute, Briefing Note 1702, London.

Eberhard, A., \& Godinho, C. (2017). A Review and Exploration of the Status, Context and Political Economy of Power Sector the reform in Sub-Saharan Africa, South Asia, and Latin America. MIR Working Paper, University of Cape Town. https://doi.org/10.1596/978-0-8213-8455-8

Eberhard, A., Rosnes, O., Shkaratan, M., \& Vennemo, H. (2011). Africa's Power Infrastructure Investment, Integration, Efficiency. DID-Infrastructure, World Bank, Washington D.C

Erdogdu, E. (2013). Essays on Electricity Market Reforms: A Cross-Country Applied Approach. Ph.D. Thesis, University of Cambridge, UK.

Fisher, R., Gutierrez, R., \& Serra, P. (2004). The Effects of Privatization on Firms and Social Welfare: The Chilean Case. Research Network Working Paper no.456 (May), Latin America Research Network, Inter-American Development Bank, Washington. https://doi.org/10.2139/ssrn.1814714

Ghanadan, R., \& Eberhard, A. (2007). Electricity utility management contracts in Africa: Lessons and Experience from the TANESCO-NET Group Solutions Management Contract in Tanzania, 2002-2006. MIR Working Paper, Management Programme for Infrastructure Reform and Regulation, Cape Town.

Godinho, C., \& Eberhard, A. (2018). Power Sector Reform and Regulation in Tanzania. Tanzania Institutional Diagnostic, WP18/TID07 Economic Development and Institutions.

Govinda, R. T, Jamasb, \& Nepal, R. (2015). Electricity Sector Reform in Developing Countries: A Survey of Empirical Evidence on Determinants and Performance.

Gratwick, K. N., \& Eberhard, A. (2008). An Analysis of Independent Power Projects in Africa: Understanding Development and Investment Outcomes. Development Policy Review, 26(3), 309-338. https://doi.org/10.1111/j.1467-7679.2008.00412.x

Jamasb, T., Mota, R., Newberry, D., \& Pollitt M. (2005). Electricity Sector Reform in Developing Countries: A Survey of Empirical Evidence on Determinants and Performance. World Bank Policy Research Working Paper 3549, World Bank, March, Washington, DC. https://doi.org/10.1596/1813-9450-3549

Jamasb, T., Sen. A., \& Nepal, R. (2016). Reforming Electricity the reform: Empirical Evidence from Non-OECD Asian Economies. Oxford Institute for Energy Studies, 57 Woodstock Rd, Oxford OX2 6FA, United Kingdom, pp 1- 45.

Kapika, J., \& Eberhard, A. (2010). Assessing Regulatory Performance: The case of the Namibian Electricity Supply Industry, Graduate School of Business. Journal of Energy in Southern Africa, 21(4), 7-14. https://doi.org/10.17159/2413-3051/2010/v21i4a3258

Karekezi, S., \& Kimani, J. (2002). Status of power sector reform in Africa: impact on the poor. Energy Policy, Elsevier, 30(11), 923-945. https://doi.org/10.1016/S0301-4215(02)00048-4

Kessides, I. (2012). The Impacts of Electricity Sector Reforms in Developing Countries. The Electricity Journal, 25(6), 79-8. https://doi.org/10.1016/j.tej.2012.07.002

Lee, D. A., \& Usman, Z. (2018). Taking Stock of the Political Economy of Power Sector the reform in Developing Countries. Policy Research Working Paper 8518, World Bank, Washington D.C. https://doi.org/10.1596/1813-9450-8518

Mwandosya, J. M. (2013). "Uthibiti wa Huduma za Kiuchumi Tanzania” E and D Vision Publishing, Dar es Salaam, Tanzania.

NAO. (2017). Annual General Report of The Controller and Auditor General on The Audit of Public Authorities and Other Bodies for The Financial Year 2015/2016. United Republic of Tanzania, National Audit Office, Dar es Salaam.

NAO. (2020). Public Authorities and Other Bodies Annual General Report of the Controller and Auditor-General for The Financial Year 2018/2019. National Audit Office, United Republic of Tanzania, Dar es Salaam.

Nepal, R., \& Jamasb, T. (2012). Reforming the Power Sector in Transition: Do Institutions Matter? Energy Economics, 34(5), 1675-1682. https://doi.org/10.1016/j.eneco.2012.02.002

Pollitt, M. (1995). Ownership and Performance in Electric Utilities: The International Evidence on Privatization and 
Efficiency. Oxford University Press, Oxford

Pombo, C., \& Taborda, R. (2006). Performance and Efficiency in Colombia's Power Distribution system: Effects of the 1994 Reform. Energy Economics, 28(3), 339-369. https://doi.org/10.1016/j.eneco.2005.08.001

Poudineh, R., \& Peng. D. (2016). Sustainable Electricity Pricing for Tanzania, the Oxford Institute for Energy Studies. University of Oxford.

Pueyo, A., \& Bawakyillenuo, S. (2017). Green Power for Africa: Overcoming the Main Constraints. IDS Bulletin Transforming Development Knowledge. https://doi.org/10.19088/1968-2017.169

Quiggin, J. (2014). Electricity Privatization in Australia: A Record of Failure. the Victoria Branch of the Electrical Trade Union, Australia.

Rud, L. (2009). Essays on Electricity Markets, Institute for Research in Economics and Business Administration, Bergen.

Sen, A., Nepal, R., \& Jamasb, T. (2016). Have model, Will reform: Assessing the Outcomes of Electricity Reforms in Non-OECD Asia. The Energy Journal, 39(4), 181-210. https://doi.org/10.5547/01956574.39.4.asen

Siami-Namini, S. (2017). Reverse Privatization and New Government Reforms: A Review of Theory and Evidence. International Journal of Current Advanced Research, 6, 6846-6856.

Ullah, K. (2015). Reforming the Power, An Institutional Analysis of Power Sector Reforms in Pakistan. Ph.D. Thesis, University of Twente.

Victor, D., \& Heller, T. C. (2008). The Political Economy of Power Sector Reforms: The Experiences of Five Major Developing Countries. Cambridge University Press. https://doi.org/10.1017/CBO9780511493287

Wooders, P., Bridle, R., \& Nguyen, T. C. (2014). A Financially Sustainable Power Sector: Developing Assessment Methodologies. the International Institute for Sustainable Development.

World Bank. (2009). Monitoring Performance of Electric Utilities: Indicators and Benchmarking in Sub-Saharan Africa.

World Bank. (2013). Document of The World Bank for Official Use Only Report No. 74994-Tz. A First Power and Gas Sector Development Policy Operation.

World Bank. (2013). Private Participation in Infrastructure in Developing Countries: Trends, Effects, and Policy Lessons. World Bank, Washington D.C.

World Bank. (2016). Financial Viability of the Electricity Sector in Developing Countries: Recent Trends and Effectiveness of World Bank Interventions. World Bank, Washington D.C.

World Bank. (2017). United Republic of Tanzania Systematic Country World Bank. Dar es Salaam.

World Bank. (2018). The World Bank Research Observer, 33(1), 65-102. https://doi.org/10.1093/wbro/lkx007

Yang, J., \& Urpelainen, J. (2019). Global Patterns of Power Sector Reform, 1982-2013. Energy Strategy Reviews, 23, 152-162. https://doi.org/10.1016/j.esr.2018.12.001

Zhang, Y., Parker, D., \& Kirkpatrick, C. (2008). Electricity Sector Reform in Developing Countries: An Econometric Assessment of the Effects of Privatization, Competition, and Regulation: Journal of Regulatory Economics, 33(2), 159-178. https://doi.org/10.1007/s11149-007-9039-7 


\section{Appendix 1: Reforms Status in Tanzania}

\begin{tabular}{|c|c|c|c|c|}
\hline Year & Policy Dimension & Key Features & Status: Tanzania & Remarks \\
\hline 1992 & $\begin{array}{l}\text { Independent Power } \\
\text { producers }\end{array}$ & $\begin{array}{l}\text { Independent power producers (IPPs) are } \\
\text { private companies that participate in } \\
\text { power generation for sale to end-users } \\
\text { or SOUs. They are introduced as the } \\
\text { quickest way to increase the installed } \\
\text { capacity, private investment, and } \\
\text { competition in the sector and unburden } \\
\text { governments from funding the new } \\
\text { power plants }\end{array}$ & $\begin{array}{l}\checkmark \text { In } 1992 \text { the national energy policy } \\
\text { passed lifting TANESCO's } \\
\text { monopoly in power generation and } \\
\text { distribution segments. } \\
\checkmark \text { In } 1993 \text { bids for IPPs tendered } \\
\text { leading to the entry of IPTL-103 } \\
\text { MW (2002 online) and Songas -189 } \\
\text { MW (2004). }\end{array}$ & Introduced \\
\hline 1993 & Commercialization & $\begin{array}{l}\text { Commercialization entails observing } \\
\text { the norms of the private sector of } \\
\text { operating for profit, maximizing } \\
\text { efficiency, moving to full-cost recovery, } \\
\text { introducing cost-cutting measures, } \\
\text { reducing staff, reducing or removing } \\
\text { subsidies, and enforcing collections of } \\
\text { electricity bills. }\end{array}$ & $\begin{array}{l}\checkmark \text { Initiated in } 1993 \text { under the World } \\
\text { Bank VI Project where tariffs were } \\
\text { modestly increased and prepaid } \\
\text { meters introduced } \\
\checkmark \text { Accelerated during the Net Group } \\
\text { Solutions, and in } 2010-2013 \text { when } \\
\text { EPPs were procured. } \\
\checkmark \text { Officially promoted from } 2006 \\
\text { when EWURA became operational. }\end{array}$ & Introduced \\
\hline 1995 & Competitive markets & $\begin{array}{l}\checkmark \text { Competition is an ordering force that } \\
\text { ensures efficient allocation of } \\
\text { resources, promotes rivalry between } \\
\text { suppliers, and eliminates excessive } \\
\text { profit. } \\
\checkmark \text { It involves the provision of electric } \\
\text { service by two or more rival entities in } \\
\text { the same service area whereas the } \\
\text { owners of monopoly infrastructure } \\
\text { provide equal access to new entrants } \\
\text { (competitors) on commercial terms } \\
\text { similar to what would exist in a } \\
\text { competitive market. }\end{array}$ & $\begin{array}{l}\checkmark \text { In } 1995 \text { the single buyer model was } \\
\text { introduced where TANESCO enters } \\
\text { PPAs with IPPs. Bilateral } \\
\text { agreements as well exist where IPPs } \\
\text { sell directly to the bulk-off taker. } \\
\text { The commencement of IPTL power } \\
\text { generation in the } 2002 \text { market. } \\
\checkmark \text { In } 2016 \text {, the Regulations promoting } \\
\text { competition and guaranteeing equal } \\
\text { access to monopoly infrastructure } \\
\text { were released. } \\
\checkmark \text { The first PPA was entered in } 1995 . \\
\text { IPTL became commercially } \\
\text { operational in 2002. In } 2016 \text { the } \\
\text { bilateral agreement between Dangote } \\
\text { Group Industries and Jinan Diesel } \\
\text { Engine Co. was Ltd was signed. } \\
\text { Small Power Independent } \\
\text { Distributors Producers such as } \\
\text { Mwenga Power Services Limited } \\
\text { and Andoya Hydro Electric Power } \\
\text { Company Limited }\end{array}$ & Introduced \\
\hline 1997 & Privatization & $\begin{array}{l}\text { Private investors are allowed to invests } \\
\text { in the sector previously under state } \\
\text { monopoly. It includes the transfer of } \\
\text { public property or business to a private } \\
\text { entity through outright sale of assets, } \\
\text { joint venture, or disposal of shares in } \\
\text { the stock market; outsourcing } \\
\text { operations to a private firm for a } \\
\text { specific period (concessions } \\
\text { agreement); involving the private sector } \\
\text { in management (management and lease } \\
\text { contracts); and constructing new } \\
\text { projects that are either entirely private } \\
\text { or a public-private partnership; } \\
\text { deregulation of the sector. }\end{array}$ & $\begin{array}{l}\checkmark 1997 \text { TANESCO was specified for } \\
\text { privatization though the decision } \\
\text { was reversed in } 2005 \\
\checkmark \text { In } 2001 \text { the } 112 \text { MW power plant } \\
\text { and Songo-Songo gas facilities were } \\
\text { privatized to Songas } \\
\checkmark \text { In } 2003 \text {, a concession was awarded } \\
\text { to Artumas Group to supply power } \\
\text { to Mtwara and Lindi Regions. } \\
\checkmark \text { Between 2002-2005 TANESCO } \\
\text { was under the private management } \\
\text { of NetGroup Solutions from South } \\
\text { Africa. }\end{array}$ & Introduced \\
\hline 2001 & Independent Regulation & $\begin{array}{l}\text { Independent regulation involves } \\
\text { separating the regulatory roles from the } \\
\text { government bodies and granting the } \\
\text { new organ the right and freedom to } \\
\text { decide on regulatory matters without } \\
\text { prior consent from the government. }\end{array}$ & $\begin{array}{l}\checkmark \text { Energy and Water Utilities } \\
\text { Regulatory Authority (EWURA) to } \\
\text { regulate electricity, waters and } \\
\text { natural gas, and petroleum } \\
\text { downstream segment. }\end{array}$ & Introduced \\
\hline
\end{tabular}




\begin{tabular}{|c|c|c|c|c|}
\hline 2002 & Corporatization & $\begin{array}{l}\checkmark \text { Corporatization is transforming a } \\
\text { utility company into an independent } \\
\text { legal entity governed by the principles } \\
\text { of corporate law such as greater } \\
\text { operational autonomy, clear } \\
\text { commercial objectives and } \\
\text { performance targets, effective } \\
\text { monitoring systems; and a high degree } \\
\text { of financial independence and } \\
\text { transparency. } \\
\checkmark \text { Separate utility from ministry, create } \\
\text { a clear accounting framework and } \\
\text { provide greater operational autonomy. }\end{array}$ & $\begin{array}{l}\checkmark \text { In } 1931 \text { the Electricity Ordinance } \\
\text { established two quasi-private } \\
\text { companies: DARESCO and } \\
\text { TANESCO which were merged in } \\
1964 \text {. } \\
\checkmark \text { In } 1975 \text { the government acquired } \\
\text { EPLC's shares in TANESCO. } \\
\checkmark \text { In } 2002 \text { the incumbent TANESCO } \\
\text { was officially corporatized under the } \\
\text { Companies Act of } 2002 \text { clarifying its } \\
\text { mandates against the parent } \\
\text { ministry. }\end{array}$ & Introduced \\
\hline 2005 & $\begin{array}{l}\text { Rural Energy Fund and } \\
\text { Agency }\end{array}$ & $\begin{array}{l}\checkmark \text { Commercial and Non-commercial } \\
\text { electrification expansion are separated } \\
\text { from the commercial left under the } \\
\text { utility mandates. } \\
\checkmark \text { The fund helps to speed up access to } \\
\text { modern energy in rural areas where the } \\
\text { private sector is unable or unwilling to } \\
\text { invest due to economic and technical } \\
\text { constraints. }\end{array}$ & $\begin{array}{l}\checkmark \text { In } 2005 \text { the legislation to form the } \\
\text { Rural Energy Agency and Rural } \\
\text { Energy Fund was passed to facilitate } \\
\text { the electrification of the } \\
\text { non-commercial segment passed. } \\
\checkmark \quad 2007 \text { REA became operational }\end{array}$ & Introduced \\
\hline 2008 & Liberalization Law & $\begin{array}{l}\checkmark \text { Involves legal mandate restructuring } \\
\text { and permitting the private sector } \\
\text { participation/ownership/imports in the } \\
\text { sector. } \\
\checkmark \text { A good law normally commercializes } \\
\text { the electrical service by encouraging } \\
\text { cost-reflective tariffs, criminalizes } \\
\text { power theft, and insulates the sector } \\
\text { from political interventions. }\end{array}$ & $\begin{array}{l}\checkmark \text { In } 2008 \text { Electricity Act was enacted } \\
\text { liberalizing the entire power supply } \\
\text { chain including reform intentions but } \\
\text { with some prohibitive clauses. } \\
\checkmark \text { Presently, there as private investors } \\
\text { in the form IPPs, Small Power } \\
\text { Producers (SPPs), Independent } \\
\text { Power Distributors (IPD), and } \\
\text { Self-generators (own use). } \\
\checkmark \text { In } 2015 \text { section 41(6) of the } \\
\text { Electricity Act that prevented IPPs } \\
\text { from selling electricity to end-users } \\
\text { lifted. }\end{array}$ & Introduced \\
\hline & Unbundling & $\begin{array}{l}\text { Unbundling entails breaking up a } \\
\text { vertically integrated state monopoly } \\
\text { company into multiple power } \\
\text { generation and distribution companies } \\
\text { that trade each other competitively, } \\
\text { raise capital from the capital markets } \\
\text { and pay dividends and taxes to } \\
\text { governments. } \\
\text { Vertical and/or horizontal unbundling, } \\
\text { create independent transmission } \\
\text { company, separate profitable parts for } \\
\text { sale to private investors. }\end{array}$ & $\begin{array}{l}\checkmark \text { Plans for unbundling TANESCO } \\
\text { remains a goal since the } 1990 \mathrm{~s}\end{array}$ & $\begin{array}{l}\text { Not } \\
\text { introduced }\end{array}$ \\
\hline
\end{tabular}

Source: Compiled by the Researcher, 2019 from the Literature review

\section{Copyrights}

Copyright for this article is retained by the author(s), with first publication rights granted to the journal.

This is an open-access article distributed under the terms and conditions of the Creative Commons Attribution license which permits unrestricted use, distribution, and reproduction in any medium, provided the original work is properly cited. 